\title{
Sosialisasi Pengelolaan Limbah Dapur Serta Program 3R (Reuse, Reduce, Recycle) Bagi Pemilik Rumah Makan dan Jasa Boga di Wilayah Kota Tasikmalaya
}

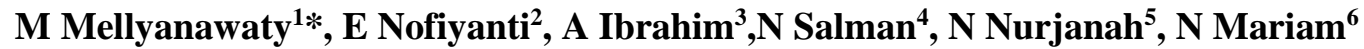 \\ 1,2,3,4,5,6 Program Studi Teknik Lingkungan Fakultas Teknik \\ Universitas Muhammadiyah Tasikmalaya \\ Email:*melly@umtas.ac.id
}

\begin{abstract}
ABSTRAK
Kegiatan pengabdian kepada masyarakat telah diselenggarakan terhadap para pemilik usaha rumah makan dan jasa boga di wilayah Kota Tasikmalaya. Kegiatan ini hasil kerja sama dengan Asosiasi Pengusaha Jasa Boga Indonesia (APJI) Cabang Tasikmalaya. Berkembangnya usaha rumah makan dan jasa boga dewasa ini menyebabkan peningkatan volume limbah yang dihasilkan. Limbah berupa limbah dapur serta limbah cair yang dihasilkan belum dapat dikelola dengan baik. Hal ini dapat menimbulkan adanya pencemaran di lingkungan sekitar serta kandungan organik yang ada menimbulkan aroma yang tidak sedap. Permasalahan yang terjadi adalah kurangnya pengetahuan mengenai pengelolaan limbah rumah makan (dapur) serta keterbatasan lahan yang ada. Pengenalan teknologi sederhana dan tidak memerlukan lahan yang terlalu luas dipandang sebagai salah satu cara untuk mengurangi permasalahan limbah dapur di Kota Tasikmalaya. Limbah padat dari rumah makan berpotensi menjadi bahan baku penghasil biogas sehingga mengurangi ketergantungan terhadap penggunaan gas elpiji. Untuk pengelolaan limbah cair rumah makan, unit pemisah lemak (grease trap) secara flotasi dilanjutkan dengan pengolahan secara fisika dan biologi diharapkan dapat menghasilkan air olahan yang sesuai dengan standar baku mutu. Kegiatan dilanjutkan dengan sosialisasi program 3R (reduce, reuse, recycle) dengan melakukan demo pemanfaatan limbah dapur seperti kemasan bekas minyak goreng, kemasan susu UHT, botol air mineral menjadi kerajinan yang dapat digunakan kembali. Transfer ilmu berjalan dengan baik dan antusiasme peserta dalam mengikuti penyuluhan sangat baik sekali.
\end{abstract}

Kata Kunci: Rumah Makan, Jasa Boga, Limbah Dapur, 3R

\begin{abstract}
Society services activity in kitchen waste management system has been implemented to the owner of restaurant and catering work in Tasikmalaya City area. This activity has colaborated with Indonesian Catering Associations (APJI). The rapid growth of restaurant and catering activities has created serious problems of energy requirement, water, and solid waste disposal. Less information and limited area become the problems in handling of kitchen waste. A simple technique is needed to overcome the environmental problem which is caused by kitchen waste. The components of kitchen waste include vegetables, peelings, fruit skins, spoilt fruit, cooked and uncooked meat, bones, fats, egg-shells, bread and pastries, cooked food waste, etc. Due to a high organic content, bioconversion technologies such as anaerobic digestion are more suitable to handle the waste convert to biogas. It would be reducing the LPG usage. For the kitchen wastewater, grease trap as pre-treatment followed by a physical and biological process is one of a simple process which can produce the effluent in accordance with government standard. The activities were continued by the socialization of $3 \mathrm{R}$ program (reuse, reduce, recycle) by doing demo utilization of kitchen solid waste such as packing material, mineral water bottle is made a handicraft. Knowledge transfer run well and the enthusiasm of the participants in following the activity were very good.
\end{abstract}

Keywords: Restaurant, Catering, Kitchen Waste, 3R 


\section{PENDAHULUAN}

\section{Analisis Situasi}

Rumah makan dan usaha jasa boga atau katering merupakan suatu usaha yang cukup berkembang pesat seiring dengan meningkatnya jumlah penduduk dan kebutuhan masyarakat untuk makan. Baik makan untuk memenuhi kebutuhan pokok sehari-hari, makan untuk sarana rekreasi maupun makan sebagai sarana untuk suatu tujuan tertentu. Jenis rumah makan yang ada di Indonesia bermacam-macam, dari mulai warung makan yang sederhana, rumah makan kecil maupun besar ataupun rumah makan cepat saji.

Namun di sisi lain, dengan berkembangnya rumah makan dan jasa boga ini menimbulkan masalah meningkatnya limbah yang dihasilkan. Limbah ini apabila langsung dibuang ke saluran atau badan air tentunya akan menimbulkan pencemaran bagi lingkungan di sekitarnya. Selain itu limbah ini memiliki kandungan organik yang tinggi sehingga menimbulkan aroma yang tidak sedap.

Bagi rumah makan atau jasaboga, limbah menjadi permasalahan penting. Limbah yang umumnya berasal dari dapur, seperti bagian dari sayuran yang tidak termasak, minyak bekas menggoreng atau sisa makanan merupakan bagian yang berkontribusi terhadap pencemaran lingkungan. Secara umum, limbah adalah bahan sisa atau buangan yang dihasilkan oleh suatu proses produksi baik skala rumah tangga maupun industri. Keberadaan limbah tidak dikehendaki karena tidak memiliki nilai ekonomis dan apabila dibuang ke lingkungan dapat menimbulkan dampak negatif.

\section{Permasalahan Mitra dan Penentuan Prioritas Masalah}

Rumah makan dan jasa boga merupakan usaha yang banyak berhubungan dengan publik dan dapat mempengaruhi kondisi kesehatan masyarakat, sehingga perlu dilakukan pengawasan. Pengelolaan limbah cair yang dihasilkan rumah makan dan jasa boga juga merupakan salah satu syarat yang harus diperhatikan seperti tertuang dalam Peraturan Menteri Kesehatan No. 1096/MENKES/PER/VI/2011 tentang Higiene Sanitasi Jasa Boga dan Peraturan Menteri Lingkungan Hidup Republik Indonesia No. 5 Tahun 2014 tentang Baku Mutu Limbah. Adapun dalam peraturan Menteri Lingkungan Hidup tersebut limbah rumah makan termasuk ke dalam kategori limbah domestik.

Masalah yang dihadapi oleh mitra saat ini adalah kurangnya pengetahuan mengenai cara pengelolaan limbah yang dihasilkan rumah makan dan jasa boga serta keterbatasan lahan yang tersedia. Sehingga limbah rumah makan dan jasa boga ini hanya dibiarkan atau dibuang begitu saja tanpa melalui pengolahan terlebih dahulu. Limbah tersebut kemudian membusuk sehingga menimbulkan aroma yang tidak menyenangkan dan mencemari lingkungan. Hal ini tentu saja merugikan warga di sekitarnya.

\section{Solusi yang Ditawarkan}

Berdasarkan permasalahan tersebut, untuk menambah pengetahuan mengenai pengelolaan limbah rumah makan dan jasa boga perlu adanya penyuluhan terkait pengelolaan limbah yang dihasilkan. Penyuluhan ini diselenggarakan bekerja sama dengan Asosiasi Pengusaha Jasaboga Indonesia (APJI) wilayah Kota Tasikmalaya.

Materi penyuluhan yang diberikan adalah terkait pengelolaan limbah dapur baik limbah padat maupun cair dengan teknologi yang sederhana berdasarkan permasalahan yang ada. Serta sosialisasi mengenai 3R (reduce, reuse, recycle) dengan memanfaatkan limbah sehingga dapat digunakan kembali. 


\section{PELAKSANAAN KEGIATAN}

\section{HASIL PELAKSANAAN KEGIATAN}

Kegiatan pengabdian kepada masyarakat dilakukan melalui kegiatan tatap muka dengan metode ceramah dan demonstrasi, dilanjutkan latihan/praktek untuk memanfaatkan limbah. Undangan diberikan kepada sekitar 40 pemilik rumah makan dan jasa boga berdasarkan anggota APJI di Kota Tasikmalaya, dengan $80 \%$ dari undangan peserta yang hadir dan sekitar $75 \%$ dari peserta yang hadir belum memahami mengenai pengelolaan limbah dapur yang baik.

\section{PEMBAHASAN HASIL PELAKSANAAN KEGIATAN}

Limbah rumah makan dan jasa boga merupakan limbah atau sampah yang berasal dari dapur, yaitu bagian dari sayuran dan bahan makanan lain yang tidak termasak dan harus dibuang seperti potongan sayuran yang tidak terpakai serta sisa makanan yang tidak habis dimakan (Singh Gill dkk., 2014). Limbah dapur yang tidak berbau dapat berasal dari kulit buah, ampas teh, ampas kopi dan sisa sayur, sedangkan yang menimbulkan bau dapat berupa sisa daging, ikan, udang, sisa makanan yang membusuk dan sebagainya. Sampah tidak mudah hancur yang sering ditemui berupa tempurung kelapa, plastik, kaleng, tulang dan lain-lain.

Selain limbah padat atau sampah, aktivitas dapur juga menghasilkan limbah cair yang berasal dari pencucian, baik pencucian sayuran, daging, ikan, piring, peralatan masak dan sebagainya. Limbah cair yang berasal dari dapur umumnya memiliki kandungan lemak (grease) yang tinggi. Kandungan lemak ini jika terakumulasi dan memadat dapat menyumbat saluran pembuangan.

\section{Limbah padat atau sampah organik}

Limbah yang dihasilkan dari aktivitas dapur umumnya mengandung material organik yang dapat digunakan sebagai pupuk kompos. Limbah berupa sayuran, buah-buahan, sisa makanan merupakan limbah organik yang berpotensi sebagai bahan baku pembuatan biogas. Limbah sayuran mempunyai rasio $\mathrm{C}: \mathrm{N}$ yang tinggi dibandingkan limbah kotoran ternak sehingga perlu ditambahkan sumber nitrogen. Limbah sayuran menghasilkan biogas delapan kali lebih banyak dibandingkan limbah kotoran ternak. Pembuatan biogas dari limbah rumah tangga seperti limbah dapur dapat menjadi solusi untuk mengurangi ketergantungan pada bahan bakar dari gas elpiji yang harganya mahal dan untuk gas elpiji bersubsidi sudah mulai langka di masyarakat. Biogas umumnya memiliki komposisi gas berupa metana atau $\mathrm{CH}_{4}$ (50\%-70\%), karbondioksida (30\%-40\%), hidrogen (5\%-10\%), nitrogen (1\%-2\%) (Karki dkk.. 2005).

Biogas dihasilkan dari proses fermentasi atau peruraian material organik secara anaerobik yang melibatkan beberapa konsorsium mikroorganisme. Biogas dihasilkan dari 3 tahapan proses dengan masing-masing proses memiliki mikroorganisme dominan yang berbeda (Andersson dkk.. 2008; Deublein dan Steinhauser 2008).

Tahap pertama adalah tahap hidrolisis. Pada tahap ini kelompok bakteri hidrolitik menguraikan material organik yang memiliki rantai panjang dan tidak larut seperti karbohidrat, protein, lemak. Perusakan ikatan ini dilakukan oleh bakteri anaerob fakultatif dan obligat (Anderson dkk., 2003; Gerardi 2003). Tahap kedua adalah tahap asidogenesis. Kelompok bakteri yang paling dominan dalam tahap ini adalah bakteri asidogen 
(pembentuk asam organik) dan asetogen (pembentuk asetat). Produk yang dihasilkan pada tahap ini adalah karbon dioksida, hidrogen, alkohol, asam organik, nitrogen, dan sulfur. Asam yang terpenting pada proses pembuatan biogas adalah asam asetat, karena merupakan asam organik utama yang digunakan sebagai substrat oleh bakteri pembentuk metana. Karbon dioksida dan hidrogen dapat dikonversi langsung menjadi asetat atau metana. Sedangkan keberadaan senyawa nitrogen dan belerang merupakan hasil degradasi protein dan asam amino. Beberapa senyawa organik diubah menjadi asam organik dan alkohol, dan beberapa dikonversi menjadi sel bakteri baru. Asam organik dan alkohol seperti asam butirat, asam propionat, dan etanol yang dihasilkan didegradasi menjadi asam asetat sebagai produk akhir kelompok bakteri asidogen.

Tahap ketiga pada proses peruraian anaerobik pembentukan biogas adalah tahap metanogenesis. Pada tahap ini bakteri yang dominan adalah bakteri metanogen yaitu kelompok bakteri yang mengonsumsi produk akhir bakteri asidogen kemudian mengonversinya menjadi metana dan karbon dioksida. (Anderson dkk., 2003). Bakteri metanogen merupakan bakteri anaerobic obligat yang sangat rentan terhadap keberadaan oksigen.

Berbagai upaya dilakukan untuk meningkatkan atau menstimulasi kinerja bakteri metanogen untuk meningkatkan produksi metana. Milán dkk. (2003) menambahkan Mg, Co dan Ni pada serbuk zeolit sebagai media imobilisasi pada proses peruraian limbah kotoran babi, dan mampu meningkatkan produksi metana berturut-turut sebesar 8,5; 4,4 dan 2,8 kali. Purnomo dkk., (2017) menambahkan trace element berupa kation Fe pada media imobiliasi zeolit dapat meningkatkan produksi biogas sebesar $25 \%$ dari limbah stillage pada konentrasi Chemical Oxygen Demand (COD) $50000 \mathrm{mg} / \mathrm{L}$.

Penambahan inokulum pada proses peruraian anaerobik diperlukan untuk mempersingkat fase start up (lag fase). Inokulum yang banyak digunakan adalah limbah kotoran sapi, limbah biodiesel (Ayu dkk., 2017) atau limbah pabrik tahu. Selain berfungsi untuk mempercepat fase start up, penambahan inokulum juga terkadang dimaksudkan untuk penyesuaian $\mathrm{pH}$ dan rasio $\mathrm{C} / \mathrm{N}$ agar proses dapat berjalan baik.

Beberapa parameter yang berpengaruh pada proses peruraian anaerobik adalah: temperatur, $\mathrm{pH}$, volatile fatty acid (VFA), keberadaan inhibitor, nutrien.

a. Temperatur

Temperatur merupakan salah satu faktor penting yang mempengaruhi aktivitas bakteri dalam sebuah proses peruraian anaerobik dan produksi metana sangat tergantung pada temperatur. Proses peruraian dapat terjadi pada dua kondisi temperatur yaitu: mesofilik dan termofilik. Temperatur yang biasa digunakan untuk proses peruraian anaerobik adalah sekitar $37^{\circ} \mathrm{C}$ (mesofilik) atau $55^{\circ} \mathrm{C}$ (termofilik) karena mikroorganisme tumbuh baik pada kondisi ini (Schnürer dan Jarvis 2010).

b. $\mathrm{pH}$

Nilai $\mathrm{pH}$ baha baku pembuatan biogas pada proses peruraian anaerobik mempengaruhi pertumbuhan bakteri metanogen dan penguraian beberapa senyawa penting seperti amonia, sulfida dan asam organik. Pembentukan gas metana $\left(\mathrm{CH}_{4}\right)$ terjadi pada kondisi $\mathrm{pH}$ antara 5,5-8,5, dengan kisaran optimal antara 7,0-8,0 untuk sebagian bakteri metanogen. Sedangkan kisaran $\mathrm{pH}$ optimum untuk proses peruraian organic mesofilik adalah $6,5-8,0$ dan proses ini akan terhambat jika nilai $\mathrm{pH}$ menurun di bawah 6,0 atau naik di atas 8,3. Namun kelarutan gas karbondioksida dalam air menurun dengan meningkatnya suhu, sehingga $\mathrm{pH}$ dalam digester termofilik akan lebih tinggi dibandingkan dengan mesofilik (Seadi dkk., 2008).

c. Volatile Fatty Acid (VFA) 
Volatile fatty acid merupakan produk antara yang dihasilkan pada tahap asidogenesis dan digunakan sebagai indikator efisiensi peruraian anaerobik. Jika konsentrasi VFA pada proses anaerobik tinggi maka akan menyebabkan penurunan $\mathrm{pH}$ sehingga mengganggu aktivitas bakteri metanogen dan mengakibatkan kegagalan proses peruraian anaerobik (Jha dkk., 2013). Akan tetapi dengan adanya akumulasi VFA tidak selalu ditandai dengan perubahan $\mathrm{pH}$ menjadi asam, karena kapasitas buffer dalam substrat melalui jenis biomassa yang terkandung di dalamnya (Seadi dkk., 2008).

d. Pengaruh inhibitor

Beberapa senyawa dapat mengganggu proses pembentukan biogas. Bakteri yang paling sensitif dan pertama terganggu adalah bakteri metanogen. Referensi mengenai inhibitor yang disebabkan oleh senyawa toksik sangat bervariasi. Hal ini dikarenakan perbedaan inokulum yang digunakan, jenis dan komposisi substrat, metode dan kondisi operasi. Selain itu karena kompleksitas proses peruraian anaerobic dan adanya mekanisme antagonisme, sinergisme, serta aklimatisasi secara signifikan dapat mempengaruhi pengaruh inhibitor. Pengaruh inhibitor dapat bervariasi. Proses dapat merespon dengan cara yang berbeda, tergantung pada beberapa faktor seperti konsentrasi inhibitor, suhu, $\mathrm{pH}$, konsentrasi dan jenis mikroorganisme (Chen dkk., 2008, Schnürer dan Jarvis 2010). Beberapa senyawa yang dapat berpengaruh sebagai inhibitor pada konsentrasi tertentu adalah: ammonia, sulfida, ion logam, senyawa organik.

e. Nutrien

Nutrien merupakan kebutuhan makanan bagi organisme. Nutrien terbagi menjadi dua yaitu makro dan mikro nutrien. Kedua nutrien ini merupakan bahan penting bagi keberhasilan proses peruraian anaerobik. Keberadaan dan kekurangannya dapat meningkatkan atau menurunkan fungsi proses fermentasi. Dua makronutrien penting yang harus tersedia dalam proses peruraian anaerobic adalah nitrogen dalam bentuk amoniumnitrogen $\left(\mathrm{NH}_{4}-\mathrm{N}\right)$ dan fosfor sebagai ortofosfat-fosfor $\left(\mathrm{HPO}_{4}-\mathrm{P}\right)$. Mikroorganisme anaerob yang terlibat dalam proses pembentukan metana memiliki syarat inheren untuk mikronutrien sebagai trace element, seperti nikel (Ni), kobalt (Co), besi (Fe) dan seng ( $\mathrm{Zn})$ (Gerardi 2003; Seadi dkk., 2008; Takashima dkk., 2011; Ivan 2012). Penambahan trace element (Fe, Co, Ni, Zn) dilakukan oleh Patidar dan Tare (2006) pada substrat sintetis, dengan sumber karbon berasal dari sejenis gula merah (gula India). Adanya penambahan trace element tersebut, memberikan stimulasi maksimum terhadap bakteri metanogen dan bakteri pereduksi sulfat. Mikronutrien berupa logam berat pada konsentrasi rendah dapat berperan sebagai trace element, namun pada konsentrasi tinggi menimbulkan efek toksik terhadap bakteri.

f. Oksigen

Mayoritas bakteri asidogen bersifat anaerobik fakultatif, sehingga tanpa adanya oksigen tidak mempengaruhi aktivitasnya. Namun bagi bakteri metanogen, oksigen dapat menginhibisi pada konsentrasi $0,1 \mathrm{mg} / \mathrm{L}$. Sebagai pengganti oksigen mereka mengambil nitrat, sulfat atau karbonat dan berperan sebagi hidrogen akseptor (Deublein dan Steinhauser 2008).

Dengan demikian kondisi tempat proses pembentukan biogas harus dijaga agar bebas oksigen supaya proses dapat berjalan optimal. Pembentukan biogas dengan bahan baku berupa sampah atau limbah organik terlebih dikumpulkan di satu tempat. Sampah organik dalam jumlah tertentu dicampurkan dengan bakteri anaerob pembangkit metana (inokulum). Proses fermentasi berlangsung dalam wadah yang disebut digester yang dibuat dari material fiberglass dalam waktu tertentu. Proses awal berlangsung selama 5 hingga 7 hari, maka selanjutnya bahan baku sampah dapat ditambahkan berikut inokulum 
bakteri anaerob, dan proses berlangsung kembali. Biogas yang dihasilkan dapat terus ditambahkan/dialirkan ke dalam tabung penampung kedap udara (tanpa oksigen). Biogas yang dihasilkan ini dapat digunakan sebagai bahan bakar pengganti gas elpiji.

\section{Limbah Cair Dapur}

Berdasarkan Peraturan Menteri Lingkungan Hidup Republik Indonesia No. 5 Tahun 2014 tentang Baku Mutu Limbah, limbah cair rumah makan termasuk ke dalam kategori limbah domestik. Limbah cair rumah makan adalah limbah yang berasal dari kegiatan operasional suatu rumah makan, mulai dari proses mempersiapkan bahan makanan yang meliputi pemilahan dan pencucian bahan baku, proses memasak, serta proses pencucian alat masak dan peralatan makan. Selain itu juga limbah yang berasal dari toilet. Dengan demikian selain senyawa organik yang terkandung dalam limbah dapur rumah makan juga mengandung detergen dari proses pencucian. Senyawa organik limbah dapur rumah makan dapat berupa karbohidrat, protein, lemak dan minyak. Teknologi sederhana dan tidak memerlukan area yang luas diperlukan untuk mengolah limbah cair yang berasal dari rumah makan agar sesuai dengan baku mutu.

Pengolahan pendahuluan untuk mengolah limbah cair dari dapur dapat berupa saringan atau screen untuk memisahkan kotoran padat berupa potongan sayuran, tulang, duri ikan, kulit buah atau sisa-sisa makanan dengan limbah cair. Selanjutnya limbah cair dialirkan ke unit pemisah lemak/minyak (grease trap). Di dalam unit ini minyak dan lemak akan terapung (flotasi). Minyak/lemak yang terapung di permukaan harus diambil secara periodik, dan limbah cair yang sudah bebas lemak dan minyak kemudian dialirkan menuju proses berikutnya.

Teknologi pengolahan limbah cair rumah makan saat ini pada umumnya menggunakan sistem dengan proses anaerob. Proses anaerob memiliki efisiensi pengolahan hanya sekitar $70-80 \%$, sehingga air hasil olahan masih mengandung kadar organik yang tinggi. Selain itu, bau yang ditimbulkan dari sistem anaerob dan tingginya kadar fosfat merupakan masalah yang belum dapat diatasi. Salah satu solusi untuk memperoleh effluent yang memenuhi syarat, dapat dilakukan dengan cara mengkombinasikan proses anaerob dan aerob yaitu proses penguraian anaerob dan diikuti dengan proses pengolahan lanjut dengan sistem biofilter anaerob aerob (Herlambang dkk., 2005). Dengan kombinasi tersebut diharapkan konsentrasi COD dalam air olahan dapat diturunkan sehingga sesuai baku mutu yang dipersyaratkan.

Pengolahan limbah modifikasi proses anaerob dan aerob, secara umum dapat diaplikasikan untuk mengolah limbah cair rumah makan dengan baik. Karena adanya berbagai sumber limbah dengan karakteristik yang berbeda, maka untuk limbah yang karakteristiknya jauh berbeda diperlukan pengolahan pendahuluan terlebih dahulu sebelum dicampur dengan limbah dari sumber lainnya. Hal ini bertujuan agar komponen polutan yang berbeda tersebut tidak mengganggu proses. Secara garis besar, diagram alir pengolahan limbah cair rumah makan disajikan pada Gambar 1. 


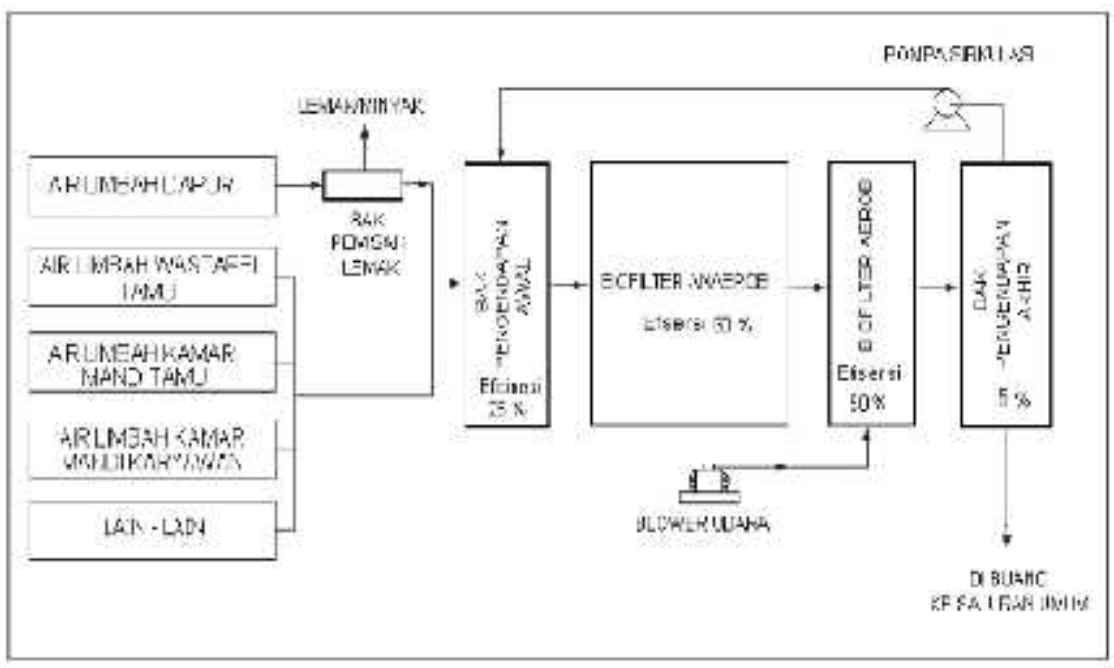

Gambar 1. Diagram alir pengolahan limbah cair rumah makan secara anaerob-aerob

(Herlambang dkk., 2005)

Limbah cair yang dihasilkan dari dapur banyak mengandung minyak dan lemak. Minyak dan lemak merupakan senyawa yang mempunyai berat jenis lebih kecil dari air, sehingga jika tidak dipisahkan terlebih dahulu dari air limbah akan membentuk lapisan di permukaan. Lapisan minyak yang terbentuk ini akan menghalangi masuknya udara ke dalam limbah, sehingga dapat mengganggu proses aerasi. Dengan demikian untuk menghindari hal tersebut maka minyak dan lemak harus dipisahkan di awal proses. Air limbah yang telah bebas minyak dan lemak dialirkan ke unit pengolahan melalui pipa inlet untuk masuk ke bak pengendapan awal. Selanjutnya dari bak pengendapan awal dialirkan ke bak anaerob. Bak anaerob tersebut terdiri dari dua ruangan yang diisi dengan media imobilisasi sebagai tempat pembiakan bakteri. Pada bak anaerob pertama air limbah mengalir dengan arah aliran dari atas ke bawah, sedangkan pada bak anaerob kedua air limbah mengalir dengan arah aliran dari bawah ke atas. Berikutnya dari bak anaerob kedua dialirkan ke bak aerob. Di dalan bak aerob tersebut air limbah dialirkan ke media imobilisasi dengan arah aliran dari atas ke bawah. Dalam bak aerob dialirkan udara melalui kompresor untuk memenuhi kebutuhan oksigen. Arah aliran udara berlawanan antara air limbah bertujuan untuk meningkatkan waktu kontak antara udara dan limbah dan untuk menungkatkan jumlah tumbukan antara udara dengan air limbah.

Setelah melalui proses aerasi, air limbah dialirkan ke bak pengendapan akhir melalui saluran yang ada di bagian bawah. Selanjutnya air olahan dialirkan ke bak klorinasi untuk membunuh bakteri yang terkandung pada air limbah hasil olahan. Air hasil olahan ini dapat digunakan untuk menyiram tanaman atau mencuci kendaraan.

Unit pengolahan jenis ini dapat dibuat dengan material beton atau paket yang telah banyak tersedia di pasaran, kemudian dipendam dengan bagian atas dapat digunakan sebagai lahan, missal tempat parker atau taman.

\section{Program reuse, reduce, recycle (3R)}

Kegiatan penyuluhan dilanjutkan dengan sosialisasi program 3R. Edukasi dan pentingnya penggunaan tas pakai ulang (reusable bag) dilakukan untuk mengurangi penggunaan tas plastik. Di akhir kegiatan dilakukan demo pemanfaatan limbah padat seperti bekas kemasan minyak goreng, botol bekas air mineral, kemasan susu UHT, gelas 
atau cup bekas air mineral. Bahan-bahan tersebut dimanfaatkan sebagai dompet, tempat pensil, dan lampu hias.

\section{HAMBATAN KEGIATAN PENGABDIAN MASYARAKAT DAN SOLUSI}

Pelaksanaan kegiatan pengabdian masyarakat ini masih sebatas penyuluhan/ceramah sehingga masih terdapat beberapa peserta yang belum memahami materi yang disampaikan. Solusi ke depan adalah dengan membuat prototype alat supaya lebih ada gambaran. Suasana penyuluhan program pengabdian masyarakat ditampilkan dalam Gambar 2.

\section{KESIMPULAN}

Program penyuluhan mengenai sosialisasi pengelolaan limbah dapur dan program $3 \mathrm{R}$ dapat diselenggarakan dengan baik dan berjalan dengan lancar sesuai dengan rencana kegiatan yang telah disusun. Kegiatan dimulai dengan observasi dan identifikasi masalah kemudian dilanjutkan dengan proses penyuluhan dan pendampingan. Transfer ilmu yang dilakukan berjalan dengan baik sehingga diharapkan mampu mengurangi permasalahan limbah baik limbah cair maupun limbah padat yang dihadapi masyarakat Kota Tasikmalaya.

\section{UCAPAN TERIMA KASIH}

Terima kasih disampaikan kepada Universitas Muhammadiyah Tasikmalaya yang telah mendanai kegiatan pengabdian ini.

\section{DAFTAR PUSTAKA}

Anderson, K., Sallis, P., \& Uyanik, S. (2003). Anaerobic Treatment Processes. In Handbook of Water and Wastewater Microbiology (pp. 391-426). Turkey: Elsevier.

Andersson, S., Kuttuva Rajarao, G., Land, C. J., \& Dalhammar, G. (2008). Biofilm formation and interactions of bacterial strains found in wastewater treatment systems. FEMS Microbiology Letters, 283(1), 83-90. http://doi.org/10.1111/j.1574-6968.2008.01149.x

Ayu, E. D., Halim, L., Mellyanawaty, M., Sudibyo, H., \& Budhijanto, W. (2017). The effect of natural zeolite as microbial immobilization media in anaerobic digestion at various concentrations of palm oil mill effluent (POME). AIP Conference Proceedings, 1840. http://doi.org/10.1063/1.4982335

Chen, Y., Cheng, J. J., \& Creamer, K. S. (2008). Inhibition of anaerobic digestion process: a review. Bioresource Technology, 99(10), 4044-64. http://doi.org/10.1016/j.biortech.2007.01.057

Deublein, D., \& Steinhauser, A. (2008). Biogas from Waste and Renewable Resources. Germany: Wiley-VCH Verlag GmbH \$ Co. KGaA.

Gerardi, M. H. (2003). The Microbiology of an Anaerobic Digesters. (M. H. Gerardi, Ed.). Canada: John Willey \$ Sons, Inc.

Herlambang, A., Nugrooho, R., Idaman Said, N., Hernaningsih, T., Raharjo Nugroho, P., Widayat, W., ... Prasetiyadi. (2005). Pengolahan Air Limbah Rumah Makan/ Restoran. In Buku Panduan Pedoman Teknis Pengelolaan Limbah Cair Kota Tegal (pp. 85-98). Retrieved from http://www.kelair.bppt.go.id/Publikasi/BukuPetnisLimbTegal/04restoran.pdf

Ivan. (2012). Effect of Ni and Co as Trace Metals on Digestion Performance and Biogas Produced from The Fermentation of Palm Oil Mill Effluent. Waste Resources, 2(2), 16-19.

Jha, A., Li, J., Zhang, L., Ban, Q., \& Jin, Y. (2013). Comparison between Wet and Dry Anaerobic Digestions of Cow Dung under Mesophilic and Thermophilic Conditions. Advances in Water 
Resource and Protection, 1(2), 28-37. Retrieved from http://www.seipub.org/awrp/paperInfo.aspx?ID=2916

Karki, A. B., Shrestha, J. N., \& Bajgain, S. (2005). Biogas as Renewable Source of Energy in Nepal: Theory and Development. Kathmandu: BSP-Nepal.

Milán, Z., Villa, P., Sánchez, E., Montalvo, S., Borja, R., Ilangovan, K., \& Briones, R. (2003). Effect of natural and modified zeolite addition on anaerobic digestion of piggery waste. Water Science and Technology: A Journal of the International Association on Water Pollution Research, 48(6), 263-9. Retrieved from http://www.ncbi.nlm.nih.gov/pubmed/14640227

Patidar, S. K., \& Tare, V. (2006). Effect of nutrients on biomass activity in degradation of sulfate $\begin{array}{llll}\text { laden organics. } & \text { Process } & \text { Biochemistry, } & \text { 489-495. }\end{array}$ http://doi.org/10.1016/j.procbio.2005.07.001

Purnomo, C. W., Mellyanawaty, M., \& Budhijanto, W. (2017). Simulation and Experimental Study on Iron Impregnated Microbial Immobilization in Zeolite for Production of Biogas. Waste and Biomass Valorization, 1-9. http://doi.org/10.1007/s12649-017-9879-z

Schnürer, A., \& Jarvis, A. (2010). Microbiological Handbook for Biogas Plants. Swedish.

Seadi, T. Al, Dominik, R., Prassl, H., \& Köttner, M. (2008). Biogas Handbook. (T. Al Seadi, Ed.). Esbjerg, Denmark: University of Southern Denmark Esbjerg. Retrieved from http://www.lemvigbiogas.com/BiogasHandbook.pdf

Singh Gill, S., Jana, A. M., \& Shrivastav, A. (2014). ANAEROBIC BACTERIAL DEGRADATION OF KITCHEN WASTE -A REVIEW. Int. J. Res. Dev. Pharm. L. Sci. International Journal of Research and Development in Pharmacy and Life Sciences, 3(2), 850854. Retrieved from https://www.omicsonline.org/open-access/anaerobic-bacterial-degradationof-kitchen-waste--a-review-.pdf

Takashima, M., Shimada, K., \& Speece, R. E. (2011). Minimum Requirements for Trace Metals (Iron, Nickel, Cobalt, and Zinc) in Thermophilic and Mesophilic Methane Fermentation from Glucose. Water Environment Research, 83(4), 339-346. http://doi.org/10.2175/106143010X12780288628895 


\section{Lampiran}

Dokumentasi kegiatan
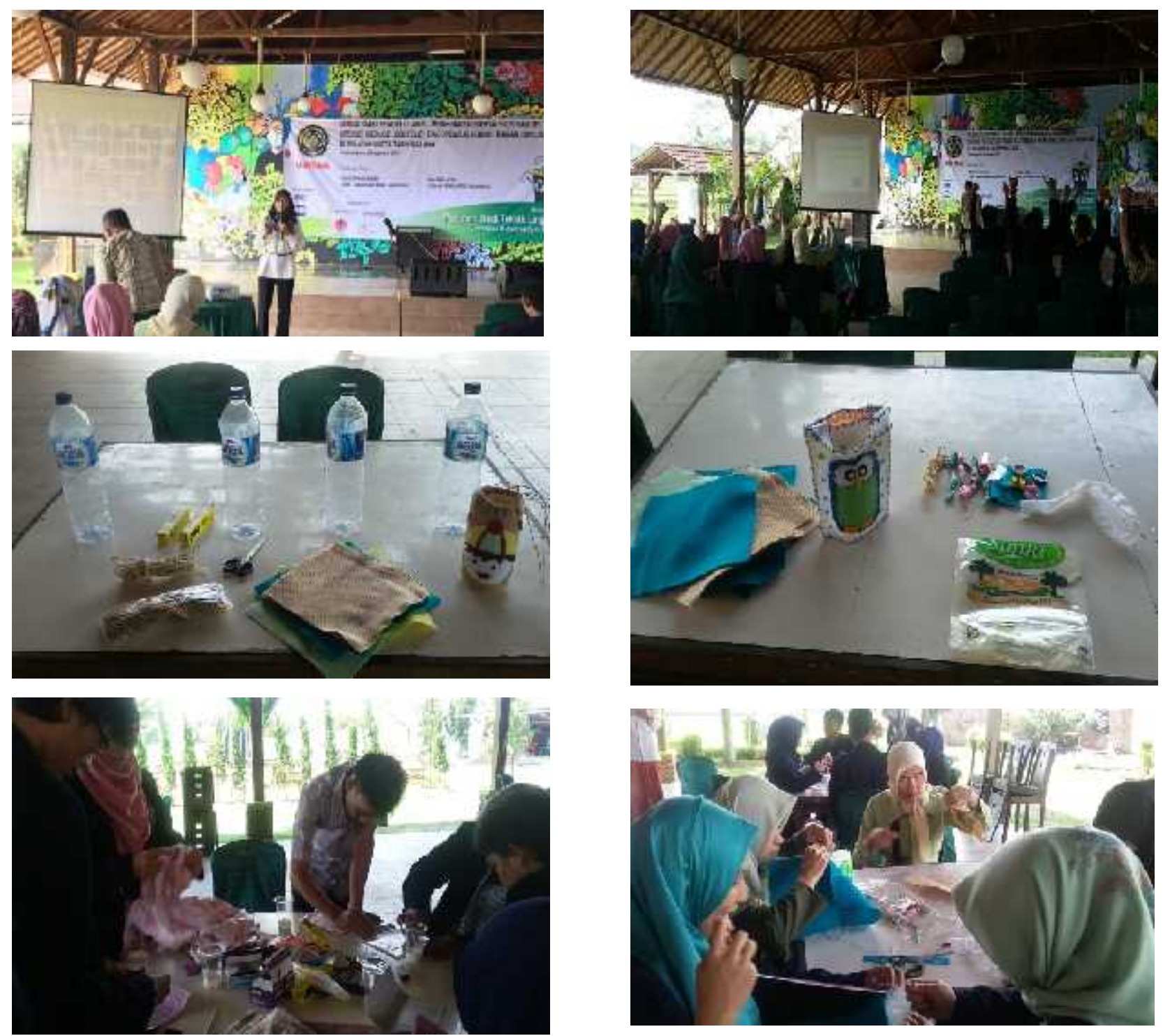